Article

\title{
Green Economy and Sustainable Development: The Economic Impact of Innovation on Employment
}

\author{
Luigi Aldieri * (1) and Concetto Paolo Vinci \\ Department of Economic and Statistical Sciences, University of Salerno, Via Giovanni Paolo II 132, \\ 84084 Fisciano, Italy; cpvinci@unisa.it \\ * Correspondence: laldieri@unisa.it;
}

Received: 6 August 2018; Accepted: 30 September 2018; Published: 2 October 2018

\begin{abstract}
The purpose of this paper is to analyze the role of the knowledge diffusion process in employment effects of sustainable development investments for large international firms. We present an empirical analysis based upon a dataset composed of worldwide Research and Development (R\&D) -intensive firms over the period 2002-2010. In order to identify the technological relatedness measure between the firms, we use the friendly environmental patents' distribution. The drivers of labor innovation effects are identified as a complex combination of job displacement and compensation forces of innovation. Two research questions are investigated: first, we wonder whether green economy investments stimulate firm-level jobs within three different environmental contexts: water, waste and energy; second, we would like to learn the extent to which the knowledge diffusion is an important channel supporting labor in the environmental context, by analysing the impact of intra-industry externalities. From the empirical results, we can observe that environmental spillovers have a negative impact, by confirming the prevalence of the displacement effect. This finding is extremely important for policy implications. Indeed, not only economic incentives to allow the transition to cleaner technologies are required, but also stronger actions to favor job creation relative to environmental activities are needed for a full sustainable achievement of firms.
\end{abstract}

Keywords: green economy; diffusion process; labor demand

JEL Classification: O33; Q55; J21

\section{Introduction}

The studies about the sustainable use of economic resources are increasing [1,2]. There are many studies investigating the link between innovation for increasing firm-level output or productivity and job-creation effect [3], where this link is found to be quite weak. This result seems to confirm the technological unemployment because of new machines [4]. Indeed, the role of automation on the employment change has become central [5].

The employment effects of innovation are a complex combination of job displacement and compensation forces of innovation [6-8]. The exploration of the impact of innovation on employment is complex, because it involves more different effects. Indeed, product innovations or the introduction of new products for the emergence of new markets $[7,8]$ can determine positive job-creation effects, while process innovations or the implementation of new and significantly improved production method $[7,8]$ could lead to technological unemployment because of increasing labor productivity. However, there are also indirect effects as a compensation for the reduction in employment stemming from process innovations. 
As far as the product innovations are concerning, we may identify a positive impact on employment $[9,10]$, the so-called 'welfare effect', but this result can be weakened by a 'substitution effect' [11-16] due to the displacement of mature products [6,17-19].

If we pay attention to process innovations, we can observe a direct job-destruction effect, because the newly introduced process method allows to obtain the same output by means of reduced employees. However, there are more compensation mechanisms $[9,20]$ in such a way that the labor-saving effect of process innovation is counterbalanced [14,21-26]. First of all, the reduced production costs from a process innovation could lead to decreasing prices and this effect could stimulate the market demand by leading to more employment [6,27-32]. However, this finding depends on the hypothesis of perfect competition [33] and demand elasticity, which might weaken the initial positive effect.

Because of the realization of more potential effects, as described, the final impact of innovation on employment is unpredictable. For this reason, the interpretation of the empirical analysis is needed to identify a net employment outcome, taking into account the economic and social context in which the investigation is applied.

The studies analyzing the effects of green innovations on employment are increasing [34,35]. This attention is due to the objective of fulfillment of more sustainable development in most countries. However, the nature of green economy investments is peculiar, because the need of government intervention to create new market opportunities could produce a lower return relative to other innovations [36].

However, the empirical evidence concerning the role of environmental innovations in the knowledge diffusion process for favoring employment is quite weak. This paper tries to fill this gap, by investigating the effects of knowledge spillovers in firms belonging to the same technological sector (intra-industry spillovers). In particular, we test for two research questions: first, we evaluate the impact of environmental innovations on employment, taking into account three different fields, such as water, waste and energy; second, we measure the effect of knowledge externalities from innovations on employment in the same technology sector.

The rest of this paper is organized as follows: Section 2 reviews the relevant empirical evidence concerning the relationship between green economy investment and employment. Section 3 describes dataset and introduces the empirical framework. Section 4 shows the results of the analysis, while Section 5 discusses the findings and concludes.

\section{Literature Review}

The research topic concerning the effect of green economy innovations on employment is receiving more and more attention because of transition to cleaner production for a full sustainable growth of industrialized countries. Moreover, high unemployment rates can be observed in these economic areas because of economic and financial crisis since 2006. More empirical studies about these structural changes are required to compare the benefits and the costs relative to the transition process.

We can distinguish studies dealing with the general nexus between technology and employment, and studies focusing on green technologies.

\subsection{Empirical Evidence Based on Technology and Employment}

As far as the macroeconomic perspective is concerned, Sinclair (1981) [37] finds that there is a positive impact on employment in case of high demand elasticity and elasticity of factor substitution. Also Layard and Nickell (1985) [38] identify the key role in the elasticity of the demand for labor with respect to a variation in the ratio between real wages and labor productivity. In particular, this parameter should be sufficiently high to compensate initial job destruction. Feldman (2013) [39] finds that technological progress produces unemployment in the short run. Matuzeviciute, Butkus and Karaliute (2017) [40] outline no significant effect of technological innovations on unemployment.

From a microeconomic perspective, Van Reenen (1997) [41] finds a positive effect of innovation on employment by using data on UK manufacturing firms. Piva and Vivarelli (2005) [42] evidence a small 
positive effect of gross innovative investment on employment. Hall, Lotti and Mairesse (2008) [19] find a positive effect of product innovation but he does not find any impact of process innovation. Bogliacino and Vivarelli (2010) [16] find a positive effect of product innovation on employment, by analyzing, particularly, high-tech manufacturing sectors in eight European countries. Lachenmaier and Rottmann (2011) [43] explore German manufacturing firms by evidencing a positive effect of different innovation measures on employment. Bogliacino and Vivarelli (2012) [44] evidence a job-creation effect of Research and Development (R\&D) expenditures in high-tech industries for 15 European countries. Harrison, Jaumandreu, Mairesse and Peters (2014) [6] confirm that process innovation lead to employment displacement, while product innovations have a labor-friendly nature. Ciriaci, Moncada-Paternò-Castello and Voigt (2016) [45] use Spanish Community Innovation Survey (CIS) on 3304 Spanish firms to demonstrate that innovative, smaller and younger firms are more likely to present a high and persistent job-creation effect than non-innovative firms. Barbieri, Piva and Vivarelli (2018) [46] investigate 265 innovative firms and outline a job-creation effect in high-tech and large firms. Cirillo, Pianta and Nascia (2018) [47] explore 36 manufacturing and service industries of five major European countries (Germany, France, Spain, Italy and the UK) and find a different impact of product innovations taking into account the managerial category with respect to other categories. Piva and Vivarelli (2018a and 2018b) [7,8] confirm a labor-friendly impact of R\&D expenditures in medium-high sectors, while they do not find any impact in low-tech sectors. Van Roy, Vertesy and Vivarelli (2018) [48] analyze about 20,000 European firms and outline that technological change, proxied by forward-citation weighted patents, are labor-friendly.

We can identify in the literature also the relevance of the role of the knowledge diffusion process in the employment effects of innovation. Indeed, Aldieri and Vinci (2018) [49] find a significant impact of technological spillovers on firms' employment within the Triad. Aldieri, Kotsemir and Vinci (2018) [50] find a labor-creation effect of own innovation and a labor-saving effect of geographical spillovers at a regional level in Russia.

There are few recent studies also about developing countries [51-53].

\subsection{Empirical Evidence Based on Green Technologies and Employment}

There are studies where environmental regulations are associated with higher production costs and higher output prices, which lead to lower demand and then to lower employment growth rate [54,55], while according to other works, environmental innovations produce a reallocation of labor from regulated to less polluting industries [56,57]. Pfeiffer and Rennings (2001) [58] evidence a positive effect of product innovation on labor, but from a qualitative perspective, they find negative effects of environmental innovations in low-skills intensive industries. Rennings and Zwick (2002) [59] analyze the environmental innovations in five European countries, taking into account both manufacturing and service firms and they do not find a significant impact on employment. Horbach (2010) [60] find a positive impact of environmental innovations on labor in Germany, while Cainelli, Mazzanti and Zoboli (2011) [61] identify a negative impact of environmental innovations on employment in Italy. Gagliardi, Marin and Miriello (2016) [35] measure the environmental innovations through patents and outline their strong positive effect on job creation processes. Costantini, Crespi and Paglialunga (2018) [62] find that energy efficiency gains in energy intensive industries reduce employment growth rate, that energy efficiency obtained in the public sector fosters employment growth and that a more comprehensive policy mix helps reinforcing positive employment growth impacts.

There are also studies where the effect of innovation on employment is found to be positive but without the distinction between environmental and no-environmental technologies [63].

In Table 1, we summarized the most recent and relevant papers discussed in this Section.

However, empirical evidence concerning the effects of friendly environmental innovations on employment and, in particular, the role of knowledge diffusion process in employment effects of green innovation is scarce. This paper tries to fill this gap in the literature. 
Table 1. Literature for employment effect of innovation.

\begin{tabular}{|c|c|c|c|}
\hline Authors & Data & Methodology & Results \\
\hline [49] & $\begin{array}{l}879 \text { firms in the USA, Europe } \\
\text { and Japan over the period } \\
\text { 2002-2010 }\end{array}$ & OLS in First Differences & $\begin{array}{l}\text { (-) negative effect of own innovation on } \\
\text { employment }\end{array}$ \\
\hline [50] & $\begin{array}{l}85 \text { Russian regions during } \\
\text { the period } 2010-2016\end{array}$ & $\begin{array}{l}\text { Generalized Method of } \\
\text { Moments (GMM) }\end{array}$ & $\begin{array}{l}\text { (+) positive effect of own innovation on } \\
\text { employment }\end{array}$ \\
\hline [46] & $\begin{array}{l}265 \text { Italian firms over the } \\
\text { period } 1998-2010\end{array}$ & Fixed-Effect (FE) & $\begin{array}{l}\text { (+) positive effect of innovation on } \\
\text { employment }\end{array}$ \\
\hline [45] & $\begin{array}{l}\text { 3304 Spanish firms over the } \\
\text { period 2002-2009 }\end{array}$ & Quantile & $\begin{array}{l}\text { (+) positive effect of innovation on } \\
\text { employment growth }\end{array}$ \\
\hline [47] & $\begin{array}{l}36 \text { industries of } 5 \text { European } \\
\text { countries during the periods } \\
2002-2007 \text { and } 2007 \text { and } 2011\end{array}$ & OLS in First Differences & $\begin{array}{l}\text { (-) negative effect of innovation on } \\
\text { employment in manufacturing } \\
\text { industries and } \\
\text { (+) positive effect of innovation on } \\
\text { employment in service industries }\end{array}$ \\
\hline [62] & $\begin{array}{l}15 \text { EU countries over the } \\
\text { time span } 1995-2009\end{array}$ & OLS in First Differences & $\begin{array}{l}(-) \text { negative effect of investments for } \\
\text { energy efficiency on employment } \\
\text { growth. }\end{array}$ \\
\hline [35] & $\begin{array}{l}4507 \text { Italian firms during the } \\
\text { period 2001-2008 }\end{array}$ & $\begin{array}{l}\text { Instrumental Variable } \\
\text { (IV) Approach }\end{array}$ & $\begin{array}{l}(+) \text { positive impact of environmental } \\
\text { innovation on employment }\end{array}$ \\
\hline [40] & $\begin{array}{l}25 \text { European countries over } \\
\text { the period } 2000-2012\end{array}$ & $\begin{array}{l}\text { Generalized Method of } \\
\text { Moments (GMM) }\end{array}$ & $\begin{array}{l}\text { No significant effect of innovation on } \\
\text { employment }\end{array}$ \\
\hline [8] & $\begin{array}{l}\text { Top European R\&D } \\
\text { investors over the period } \\
2002-2013\end{array}$ & $\begin{array}{l}\text { Least Square Dummy } \\
\text { Variable Corrected } \\
\text { (LSDVC) }\end{array}$ & $\begin{array}{l}\text { (+) positive effect of innovation on } \\
\text { employment only for medium- and } \\
\text { high-tech sectors }\end{array}$ \\
\hline [48] & $\begin{array}{l}\text { 20,000 European firms over } \\
\text { the period 2003-2012 }\end{array}$ & $\begin{array}{l}\text { Generalized Method of } \\
\text { Moments (GMM) }\end{array}$ & $\begin{array}{l}(+) \text { positive effect of innovation on } \\
\text { employment }\end{array}$ \\
\hline
\end{tabular}

\section{Data and Empirical Model}

In order to implement the econometric model, we employ data from European Commission R\&D investments Scoreboard (2011) [64]. We identify for each firm the following variables: net sales (S), the number of employees (L), the annual capital expenditures (C), annual R\&D expenditures (RD), annual operating profit (OP) and the main industry sectors according to the Industrial Classification Benchmark (ICB) at the two-digit level. Because of no information on wages, they are proxied by capital expenditures and operating profit $[49,65]$. Scoreboard dataset is rich in useful information, but it has also limitations. Indeed, it is affected by sample selection, since it includes only very large R\&D companies. This means that SMEs are not considered. However, green innovation is also important for SMEs [66].

Moreover, we use also the Organisation for Economic Co-operation and Development (OECD)'s Regional Patents (REGPAT) database from January 2012 [67] as the second source of information. This database covers firms' patent applications to the European Patent Office (EPO), including patents published up to December 2011. In particular, we select water pollution abatement, land fertilizers and waste recycling and energy patents for measuring green economy activity, in such a way that we compute technological proximity between firms $[68,69]$.

In this paper, we explore the role of the knowledge diffusion process, by focusing on the externalities stemming from firms belonging to the same sector, intra-industry or Marshallian Spillovers [70-73]. Indeed, spillovers from parent companies within the same sector are crucial [74].

In order to measure the impact of Marshallian Spillovers on firms' employment, we consider the following specification model (see Appendix A for the theoretical foundation):

$$
\ln L_{i t}=\alpha_{i}+\lambda_{t}+\beta_{1} \ln L_{i t-1}+\beta_{2} \ln S+\beta_{3} \ln C_{i t}+\beta_{4} \ln O P_{i t}+\beta_{5} \ln K_{i t}+\gamma_{1} \ln K_{R i t-1}+\varepsilon_{i t}
$$


where

ln = natural logarithm;

$L_{i t}=$ number of employees for firm $i$ and year $t$;

$S_{i t}=$ Net Sales of firm $i$ and year $t$;

$C_{i t}=$ physical capital stock for firm $i$ and year $t$;

$O P_{i t}=$ Operating Profit of firm $i$ and year $t$;

$K_{i t}=\mathrm{R} \& \mathrm{D}$ capital stock of firm $i$ and year $t$;

$\alpha_{i}=$ firm's fixed effects;

$\lambda_{t}=$ set of time dummies;

$K_{R i t-1}=$ vector of Marshallian spillovers (computed as the weighted sum of $K j$ on the basis of technological proximity matrix between the firms belonged to the same industry) for firm $i$ and year $t$;

$\beta, \gamma=$ vectors of parameters;

$\varepsilon_{i t}=$ disturbance term.

In Table 2, we show the summary statistics of our sample. In particular, we consider the R\&D capital stock based on the perpetual inventory method [75] with a 5\% initial growth rate and a $15 \%$ depreciation rate.

Table 2. Summary statistics.

\begin{tabular}{ccc}
\hline Variable & Mean $^{\text {a }}$ & Std. Dev. \\
\hline $\ln \mathrm{L}$ & 10.00 & 1.340 \\
$\ln \mathrm{L}_{(\mathrm{t}-1)}$ & 10.02 & 1.333 \\
$\ln \mathrm{C}$ & 8.53 & 1.445 \\
$\ln \mathrm{C}$ & 7.53 & 1.563 \\
$\operatorname{lnOP}$ & 4.93 & 1.892 \\
$\mathrm{LnK}$ & 7.17 & 1.419 \\
$\operatorname{lnK} \mathrm{R}_{\mathrm{r}}$ & 3.94 & 6.572 \\
\hline \multicolumn{3}{c}{ Note: $^{\text {a }}$ 1779 observations. }
\end{tabular}

\section{Results}

In order to deal with the endogeneity of the explanatory variables, we estimate Equation (1) using a one-stage generalized method of moments (GMM) estimator [76,77], which combines the standard set of equations in the first difference with suitably lagged levels as instruments (GMM in first differences), with an additional set of equations in levels with suitably lagged first differences as instruments. The validity of these additional instruments, which consist of first difference-lagged values of the regressors, can be tested through over-identification tests. The one-stage GMM (GMM SYS) estimator can lead to considerable improvements regarding efficiency compared to the GMM in first differences (GMM FD).

In Table 3, we show the empirical estimates for the GMM-SYS estimator. In particular, we evidence the direct effects of innovation $(K)$ and indirect effects through environmental spillovers $\left(\mathrm{K}_{\mathrm{R}}\right)$ on firms' employment. We lag environmental spillover components by a year to mitigate contemporaneous feedback effects.

The model specification includes country, time, and industry dummies, which capture the impact of factors that change over time but not over the cross-sectional dimension of the sample. The results of the AR (1) and AR (2) tests are consistent with the assumption of no serial correlation in the residuals in levels, and the Hansen tests do not reject the null hypothesis of valid instruments, indicating that the instruments are not correlated with the error term.

The interesting results are relative to causal effects of environmental spillovers on employment. In particular, environmental spillovers $\left(K_{R}\right)$ have a negative impact, by confirming the empirical evidence based on the negative association between environmental innovations and firms' competitiveness [54,62]. Empirical investigation allows us to answer our research questions: first, 
environmental innovations have a significant negative effect on employment; second, knowledge diffusion process through intra-industry externalities assumes a crucial role in the employment effects of innovation. This finding is extremely important for policy implications. As far as the managerial implications are concerned, the results seem to evidence the necessity for promoting marketing activities between firms of the same sector, in such a way that the ability to identify, assimilate and exploit external knowledge can become stronger. Moreover, if we consider theoretical implications of the analysis, we can realize that not only economic incentives to allow the transition to cleaner technologies are required, but also stronger actions to favor job creation relative to environmental activities are needed for a full sustainable achievement of firms.

Table 3. Labor effects of green: generalized method of moments (GMM) estimates.

\begin{tabular}{ccc}
\hline Dependent Variable: $\Delta \ln$ Lt & & \\
\hline & Estimate & S.E. ${ }^{\text {a }}$ \\
$\Delta \ln \mathrm{Lt}-1$ & $0.94^{* * *}$ & $(0.060)$ \\
$\Delta \ln \mathrm{C}$ & $0.12^{* * *}$ & $(0.043)$ \\
$\Delta \ln \mathrm{OP}$ & 0.01 & $(0.035)$ \\
$\Delta \ln \mathrm{K}$ & -0.01 & $(0.014)$ \\
$\Delta \ln \mathrm{K}_{\mathrm{R}}(t-1)$ & $-0.07^{* * *}$ & $(0.031)$ \\
$\mathrm{AR}(1)^{\mathrm{c}}$ test & $-0.01^{* * *}$ & $(0.001)$ \\
$\mathrm{AR}(2)$ test & $z=-4.89$ & $p>z=0.000$ \\
Hansen $^{\mathrm{b}}: \chi^{2}(65)=71.78$ & $z=0.36$ & $p>z=0.716$ \\
\end{tabular}

Notes: ${ }^{a}$ : heteroskedastic-consistent standard errors; ${ }^{\mathrm{b}}$ : Hansen test of over-identifying restrictions, $p$-value in squared brackets; ${ }^{c}$ : AR (1) and $\operatorname{AR}(2)$ are tests for first- and second-order serial correlation; ${ }^{* * *},{ }^{* *}$, coefficient significant at the $1 \%, 5 \%$ level respectively. Country, time and industry dummies included. Endogenous variables are net sales, physical capital, labor, operating profit, R\&D capital stock and spillovers. Instruments are lagged values (2-9) of all explanatory variables.

\section{Discussion and Concluding Remarks}

The sustainability of economic systems is extremely important to allow an efficient use of goods and services in current industrialized countries.

The paper has investigated two important questions. On one hand, the analysis has enriched the empirical evidence concerning the impact of green economy investments on firm-level jobs. On another hand, the knowledge diffusion process in the environmental contexts has been further explored by analyzing the impact of Marshallian externalities.

Indeed, we can observe many studies investigating the link between innovation for increasing firm-level output or productivity and job-creation effects, but they often ignore the indirect effects of own investments on other firms' employment. This paper tries to fill this gap in the previous literature by assuming a relevant role of knowledge process for green economy activity.

The complex combination of job displacement and compensation forces of innovation seems to be affected by knowledge spillovers. Indeed, from the empirical results, we can observe that Marshallian spillovers in green economy have a negative impact, by confirming the prevalence of the displacement effect. This finding is extremely important for policy implications. Indeed, not only economic incentives to allow the transition to cleaner technologies are required, but also stronger actions to favor job creation relative to environmental activities are needed for a full sustainable achievement of firms.

However, we can identify some limitations on the methodological approach of research, which has been developed. Indeed, our idea has been to consider the technological proximity between technology classes of environmental patents. However, Jaffe's measure has some weaknesses. Indeed, Jaffe's proximity deals with flows only occuring within the same technology class defined as Marshallian or intra-industry or specialized externalities, but rules out spillovers between different 
classes, Jacobian or inter-industry or diversified externalities [78]. In this case, we could assume other more opportune approaches $[68,79,80]$.

For this reason, further analysis is needed. Indeed, our analysis could be implemented by observing also Jacobian or inter-industry spillovers. Moreover, it would be interesting to explore the extent to which other channels of knowledge diffusion, as the mobility of skilled workers or inventors, may have a significant role on the impact of green economy investments on firms' employment.

Author Contributions: C.P.V. developed theoretical model in the Appendix A. L.A. reviews the literature, analyzed the data and implemented the empirical model in Sections 2-4. L.A. and C.P.V. wrote Sections 1 and 5.

Funding: This research received no external funding.

Acknowledgments: The authors wish to thank the editor and three anonymous reviewers for their useful comments on the previous drafts of the work.

Conflicts of Interest: The authors declare no conflict of interest.

\section{Appendix A}

In order to give a basic theoretical framework for our empirical analysis, we follow Garcia, Jaumandreu and Rodriguez (2004) [81] and consider only companies with constant returns to scale technology where different green technological classes are combined with physical, human and knowledge capital that minimize costs. The number of varieties may be endogenously determined, investments in these technological classes are assumed to move on rational agents' decisions [82].

The effects of green innovation on technology and demand function may be illustrated by the effect of the collected knowledge capital $K_{g}$. Defining respectively with: $c$ and $w$ the marginal cost, and vector inputs prices, we assume $c=c\left(w, K_{g}\right)$. Further $Y, p$ and $L$ respectively measure production of green companies, output prices, and employment; $\mu$ captures entrepreneur mark-up on the marginal $\operatorname{cost}, d^{e}$ is an index of the market dynamics, and with $K_{g R}, p_{R}$, respectively we define rival firms' accumulated Knowledge capital and output prices. We can state:

$$
\begin{gathered}
p=(1+\mu) c\left(w, K_{g}\right) \\
Y=D\left(d^{e}, p, p_{R}, K_{g}, K_{g R}\right) \\
K_{g R}=f\left(K_{g}\right) \\
p_{R}=\left(1+\mu_{R}\right) c_{R}\left(w_{R}, K_{g R}\right) \\
L=c_{L}\left(w, K_{g}\right) Y
\end{gathered}
$$

where $c_{L}$ measures the employment's marginal cost derivative (the Shepard's lemma) and $c_{R}, w_{R}, \mu_{R}$ capture respectively marginal cost, vector inputs prices and mark-up for the competing firms. Equation (4) may be revised as:

$$
L=c_{L}\left(w, K_{g}\right) D\left[d^{e},(1+\mu) c\left(w, K_{g}\right),\left(1+\mu_{R}\right) c_{R}\left(w_{R}, f\left(K_{g}\right)\right), K_{g}, f\left(K_{g}\right)\right]
$$

The short run effect of innovation on the employment level may be given by the following:

$$
\frac{\partial L}{\partial K_{g}}=\frac{\partial c_{L}}{\partial K_{g}} Y+c_{L}\left\{\frac{\partial Y}{\partial K_{g}}+\frac{\partial Y}{\partial p} \frac{\partial p}{\partial K_{g}}+\frac{\partial Y}{\partial p_{R}} \frac{\partial p_{R}}{\partial K_{g R}} \frac{\partial K_{g R}}{\partial K_{g}}+\frac{\partial Y}{\partial K_{g R}} \frac{\partial K_{g R}}{\partial K_{g}}\right\}
$$

From inspection of Equation (7) we can see as the first term on the right takes the displacement effect, while the second one measures the sum of more compensation effects:

- the first captures demand effect due to product innovation;

- the second is relative to demand effect by the drop of the cost decline owed to price; 
- the third measures the demand effect due to drops in of competing firms price via the influence on innovation of its rivals;

- the fourth takes the effect on demand due to innovations of its competitors.

Furthermore we assume that, at the beginning of the innovations' achievement, each entrepreneur bargains wages $w$ with unions, keeps in mind prices dynamics' changes (deviations in $\mu$ and in $\mu_{R}$ ) according to a different competitive environment owed to innovation, by denoting with $z$ and $z_{R}$ other possible reasons of changes on wages and mark-ups, we introduce what follows:

$$
\begin{gathered}
w=w\left(z, K_{g}\right) \\
w_{R}=w_{R}\left(z_{R}, K_{g R}\right) \\
\mu=\mu\left(z, K_{g}\right) \\
\mu_{R}=\mu_{R}\left(z_{R}, K_{g R}\right)
\end{gathered}
$$

Therefore Equation (A6) will turn in:

$$
\begin{gathered}
L=c_{L}\left(w\left(z, K_{g}\right), K_{g}\right) D\left[d^{e},\left(1+\mu\left(z, K_{g}\right)\right) c\left(w\left(z, K_{g}\right), K_{g}\right),\right. \\
\left.\left(1+\mu_{R}\left(z_{R}, f\left(K_{g}\right)\right)\right) c_{R}\left(w_{R}\left(z_{R}, g\left(K_{g}\right)\right), f\left(K_{g}\right)\right), K_{g}, f\left(K_{g}\right)\right]
\end{gathered}
$$

The short-run innovation effect on employment will become:

$$
\begin{gathered}
\frac{\partial L}{\partial K_{g}}=\left[\frac{\partial c_{L}}{\partial K_{g}}+\frac{\partial c_{L}}{\partial w} \frac{\partial w}{\partial K_{g}}\right] Y+c_{L} \\
\left\{\frac{\partial Y}{\partial K_{g}}+\frac{\partial Y}{\partial p}\left\{\frac{\partial \mu}{\partial K_{g}} c+(1+\mu)\left[\frac{\partial c}{\partial w} \frac{\partial w}{\partial K_{g}}+\frac{\partial c}{\partial K_{g}}\right]\right\}+\right. \\
\left.\frac{\partial Y}{\partial p_{R}}\left[c_{R}\left\{\frac{\partial \mu_{R}}{\partial K_{g} R} \frac{\partial K_{g}}{\partial K_{g}}\right\}+\left(1+\mu_{R}\right)\left\{\frac{\partial c_{R}}{\partial w_{R}} \frac{\partial w_{R}}{\partial K_{g} R} \frac{\partial K_{g R}}{\partial K_{g}}+\frac{\partial c_{R}}{\partial K_{g R} R} \frac{\partial K_{g R}}{\partial K_{g}}\right\}\right]+\frac{\partial Y}{\partial K_{g R}} \frac{\partial K_{g R}}{\partial K_{g}}\right\}
\end{gathered}
$$

We may perceive as introducing conditions (Equations (A8)-(A11)) alter both the displacement and the compensation effects.

\section{References}

1. Arbolino, R.; Carlucci, F.; Cirà, A.; Ioppolo, G.; Yigitcanlar, T. Efficiency of the EU regulation on greenhouse gas emissions in Italy: The hierarchical cluster analysis approach. Ecol. Indic. 2017, 81, 115-123. [CrossRef]

2. Arbolino, R.; De Simone, L.; Carlucci, F.; Yigitcanlar, T.; Ioppolo, G. Towards a sustainable industrial ecology: Implementation of a novel approach in the performance evaluation of Italian regions. J. Clean. Prod. 2018, 178, 220-236. [CrossRef]

3. Van Zandweghe, W. Why have the dynamics of labor productivity changed? Fed. Reserv. Bank Kans. City Econ. Rev. 2000, 95, 5-30.

4. Brynjolfsson, E.; McAffe, A. Race against the Machine: How the Digital Revolution Is Accelerating Innovation, Driving Productivity, and Irreversibly Transforming Employment and the Economy; Digital Frontier Press: Lexington, MA, USA, 2011.

5. Vermeulen, B.; Kesselhut, J.; Pyka, A.; Saviotti, P.P. The Impact of Automation on Employment: Just the Usual Structural Change? Sustainability 2018, 10, 1661. [CrossRef]

6. Harrison, R.; Jaumandreu, J.; Mairesse, J.; Peters, B. Does innovation stimulate employment? A firm-level analysis using comparable micro-data from four European countries. Int. J. Ind. Organ. 2014, 35, 29-43. [CrossRef]

7. Piva, M.; Vivarelli, M. Technological change and employment: Is Europe ready for the challenge? Eurasian Bus. Rev. 2018, 8, 13-32. [CrossRef]

8. Piva, M.; Vivarelli, M. Is Innovation Destroying Jobs? Firm-Level Evidence from the EU. Sustainability 2018, 10, 1279. [CrossRef]

9. Marx, K. Capital; Foreign Languages Publishing House: Pyongyang, Korea, 1961. First published 1867. 
10. Say, J.B. A Treatise on Political Economy or the Production, Distribution and Consumption of Wealth; M. Kelley: New York, NY, USA, 1964. First published 1803.

11. Freeman, C.; Clark, J.; Soete, L. Unemployment and Technical Innovation; Pinter Publishers: London, UK, 1982.

12. Freeman, C.; Soete, L. Technical Change and Full Employment; Bail Blackwell: Oxford, UK, 1987.

13. Freeman, C.; Soete, L. Work for All or Mass Unemployment? Computerized Technical Change into the Twenty-First Century; Pinter Publishers: London, UK, 1994.

14. Vivarelli, M.; Pianta, M. The Employment Impact of Innovation: Evidence and Policy; Routledge: Abingdon-on-Thames, UK, 2000.

15. Edquist, C.; Hommen, L.; Mckelvey, M. Innovation and Employment: Product versus Process Innovation; Edward Elgar Publishing: Cheltenham, UK, 2001.

16. Bogliacino, F.; Vivarelli, M. Innovation and Employment: A reinvestigation using Pavitt classes. Res. Policy 2010, 39, 799-809. [CrossRef]

17. Katsoulacos, Y.S. Product innovation and employment. Eur. Econ. Rev. 1984, 26, 83-108. [CrossRef]

18. Katsoulacos, Y.S. The Employment Effect of Technical Change; Wheatsheaf: London, UK, 1986.

19. Hall, B.H.; Lotti, F.; Mairesse, J. Employment, innovation, and productivity: Evidence from Italian microdata. Ind. Corp. Chang. 2008, 17, 813-839. [CrossRef]

20. Marx, K. Theories of Surplus Value; First Edition 1905-1910; Lawrence \& Wishart: London, UK, 1969.

21. Petit, P. Employment and Technological Change. In Handbook of the Economics of Innovation and Technological Change; Stoneman, P., Ed.; Wiley-Blackwell: North Holland, The Netherlands, 1995; pp. 366-408.

22. Vivarelli, M. The Economics of Technology and Employment: Theory and Empirical Evidence; Edward Elgar Publishing: Cheltenham, UK, 1995.

23. Vivarelli, M. Technology, employment and skills: An interpretative framework. Eurasian Bus. Rev. 2013, 3 , 66-89.

24. Vivarelli, M. Innovation, employment and skills in advanced and developing countries: A survey of economic literature. J. Econ. Issues 2014, 48, 123-154. [CrossRef]

25. Pianta, M. Innovation and Employment. In Handbook of Innovation; Fagerberg, J., Mowery, D., Nelson, R.R., Eds.; Oxford University Press: Oxford, UK, 2005; pp. 568-598.

26. Coad, A.; Rao, R. The firm-level employment effects of innovations in high-tech US manufacturing industries. J. Evol. Econ. 2011, 21, 255-283. [CrossRef]

27. Pigou, A. The Economics of Welfare; Macmillan: London, UK, 1962. First published 1920.

28. Neary, J.P. On the short-run effects of technological progress. Oxf. Econ. Pap. 1981, 33, 224-233. [CrossRef]

29. Stoneman, P. The Economic Analysis of Technological Change; Oxford University Press: Oxford, UK, 1983.

30. Hall, P.H.; Heffernan, S.A. More on the employment effects of innovation. J. Dev. Econ. 1985, 17, 151-162. [CrossRef]

31. Dobbs, I.M.; Hill, M.B.; Waterson, M. Industrial structure and the employment consequences of technical change. Oxf. Econ. Pap. 1987, 39, 552-567. [CrossRef]

32. Smolny, W. Innovations, prices and employment: A theoretical model and an empirical application for West German manufacturing firms. J. Ind. Econ. 1998, 46, 359-381. [CrossRef]

33. Sylos Labini, P. Oligopoly and Technical Progress; Harvard University Press: Cambridge, MA, USA, 1969. First published 1956.

34. Crespi, F.; Ghisetti, C.; Quatraro, F. Environmental and innovation policies for the evolution of green technologies: A survey and a test. Eurasian Bus. Rev. 2015, 5, 343-370. [CrossRef]

35. Gagliardi, L.; Marin, G.; Miriello, C. The greener the better? Job creation effects of environmentally-friendly technological change. Ind. Corp. Chang. 2016, 25, 779-807. [CrossRef]

36. Marin, G.; Lotti, F. Productivity effects of eco-innovations using data on eco-patents. Ind. Corp. Chang. 2017, 26, 125-148. [CrossRef]

37. Sinclair, P.J.N. When will technical progress destroy jobs? Oxf. Econ. Pap. 1981, 31, 1-18. [CrossRef]

38. Layard, R.; Nickell, S. The causes of British unemployment. Natl. Inst. Econ. Rev. 1995, 111, 62-85. [CrossRef]

39. Feldmann, H. Technological unemployment in industrial countries. J. Evol. Econ. 2013, 23, 1099-1126. [CrossRef]

40. Matuzeviciute, K.; Butkus, M.; Karaliute, A. Do technological innovations affect unemployment? Some empirical evidence from European countries. Economies 2017, 5, 48. [CrossRef] 
41. Van Reenen, J. Employment and technological innovation: Evidence from UK manufacturing firms. J. Labor Econ. 1997, 15, 255-284. [CrossRef]

42. Piva, M.; Vivarelli, M. Innovation and employment: Evidence from Italian microdata. J. Econ. 2005, 86, 65-83. [CrossRef]

43. Lachenmaier, S.; Rottmann, H. Effects of innovation on employment: A dynamic panel analysis. Int. J. Ind. Organ. 2011, 29, 210-220. [CrossRef]

44. Bogliacino, F.; Vivarelli, M. The job creation effect of R\&D expenditures. Aust. Econ. Pap. 2012, 51, 96-113.

45. Ciriaci, D.; Moncada-Paternò-Castello, P.; Voigt, P. Innovation and job creation: A sustainable relation? Eurasian Bus. Rev. 2016, 6, 189-213. [CrossRef]

46. Barbieri, L.; Piva, M.; Vivarelli, M. R\&D, embodied technological change, and employment: Evidence from Italian microdata. Ind. Corp. Chang. 2018. [CrossRef]

47. Cirillo, V.; Pianta, M.; Nascia, L. Technology and occupations in business cycles. Sustainability 2018, $10,463$. [CrossRef]

48. Van Roy, V.; Vertesy, D.; Vivarelli, M. Thechnology and employment: Mass unemployment or Job creation? Empirical evidence from European patenting firms. Res. Policy 2018. [CrossRef]

49. Aldieri, L.; Vinci, C.P. Innovation effects on employment in high-tech and low-tech industries: Evidence from large international firms within the triad. Eurasian Bus. Rev. 2018, 8, 229-243. [CrossRef]

50. Aldieri, L.; Kotsemir, M.N.; Vinci, C.P. The Role of Geographic Spillovers in Employment Policy Planning: An Empirical Investigation for Russian Regions. Foresight 2018. [CrossRef]

51. Meschi, E.; Taymaz, E.; Vivarelli, M. Trade, technology and skills: Evidence from Turkish microdata. Labor Econ. 2011, 18, S60-S70. [CrossRef]

52. Mitra, A.; Jha, A. Innovation and employment: A firm level study of Indian industries. Eurasian Bus. Rev. 2015, 5, 45-71. [CrossRef]

53. Haile, G.; Srour, I.; Vivarelli, M. Imported technology and manufacturing employment in Ethiopia. Eurasian Bus. Rev. 2017, 7, 1-23. [CrossRef]

54. Bartik, T.J. The social value of job loss and its effect on the costs of US environmental regulations. Rev. Environ. Econ. Policy 2015, 9, 179-197. [CrossRef]

55. Dechezlepretre, A.; Sato, M. The impact of Environmental Regulations on Competitiveness. Rev. Environ. Econ. Policy 2017, 11, 183-206. [CrossRef]

56. Antonioli, D.; Mancinelli, S.; Mazzanti, M. Is environmental innovation embedded within high-performance organisational change? The role of human resource management and complementarity in green business strategies. Res. Policy 2013, 42, 975-988. [CrossRef]

57. Ambec, S.; Cohen, M.A.; Elgie, S.; Lanoie, P. The Porter hypothesis at 20: Can environemntal regulation ehance innovation and competitiveness? Rev. Environ. Econ. Policy 2013, 7, 2-22. [CrossRef]

58. Pfeiffer, F.; Rennings, K. Employment impacts of cleaner production, evidence from a Germany study using case studies and surveys. Bus. Strategy Environ. 2001, 10, 161-175. [CrossRef]

59. Rennings, K.; Zwick, T. The Employment Impact of Cleaner Production on the Firm Level, Empirical Evidence from a Survey in Five European Countries. Int. J. Innov. Manag. 2002, 6, 319-342. [CrossRef]

60. Horbach, J. The Impact of Innovations Activities on Employment in the Environmental sector, Empirical results for Germany at the firm level. J. Econ. Stat. 2010, 230, 403-419. [CrossRef]

61. Cainelli, G.; Mazzanti, M.; Zoboli, R. Environmentally-oriented innovative strategies and firm performances in services: Micro evidence from Italy. Int. Rev. Appl. Econ. 2011, 25, 61-85. [CrossRef]

62. Costantini, V.; Crespi, F.; Paglialunga, E. The employment impact of private and public actions for energy efficiency: Evidence from European industries. Energy Policy 2018, 119, 250-267. [CrossRef]

63. Licht, G.; Peters, B. The Impact of Green Innovation on Employment Growth in Europe; WWWforEurope Working Paper No. 50; WWWforEurope: Vienna, Austria, 2013.

64. European Commission. The 2000-2010 EU Industrial RED Investment Scoreboard; JRC Scientific and Technical Research Series; Joint Research Center-Institute for Prospective Technological Studies; Office for Official Publications of the European Communities: Luxembourg, 2011.

65. Bogliacino, F. Innovation and Employment: A firm level analysis with European R\&D Scoreboard data. EconomiA 2014, 15, 141-154.

66. Ebrahimi, P.; Mirbargkar, S.M. Green entrepreneurship and green innovation for SME development in market turbulence. Eurasian Bus. Rev. 2017, 7, 203-228. [CrossRef] 
67. OECD. REGPAT Database; OECD Publishing: Paris, France, 2012.

68. Aldieri, L. Knowledge technological proximity: Evidence from US and European patents. Econ. Innov. New Technol. 2013, 22, 807-819. [CrossRef]

69. Aldieri, L.; Kotsemir, M.N.; Vinci, C.P. Jacobian Spillovers in Environmental Technological Proximity: The Role of Mahalanobis Index on European Patents within the Triad; MPRA Paper 77274; University Library of Munich: Munich, Germany, 2017.

70. Marshall, A. Principles of Economics; Macmillan: London, UK, 1890.

71. Arrow, K.J. The economic implications of learning by doing. Rev. Econ. Stud. 1962, 29, 155-172. [CrossRef]

72. Romer, P.M. Increasing returns and long-run growth. J. Political Econ. 1986, 94, 1002-1037. [CrossRef]

73. Glaeser, S.; Kallal, H.D.; Scheinkman, J.A.; Shleifer, A. Growth of cities. J. Political Econ. 1992, 100, 1126-1152. [CrossRef]

74. Toselli, M. Knowledge sources and integration ties toward innovation. A Food sector perspective. Eurasian Bus. Rev. 2017, 7, 43-65. [CrossRef]

75. Griliches, Z. Issues in assessing the contribution of R\&D to productivity growth. Bell J. Econ. 1979, 10, 92-116.

76. Arellano, M.; Bover, O. Another look at the instrumental-variable estimation of error-components models. J. Econom. 1995, 68, 29-52. [CrossRef]

77. Blundell, R.W.; Bond, S.R. Initial conditions and moment restrictions in dynamic panel data models. J. Econom. 1998, 87, 115-143. [CrossRef]

78. Jacobs, J. The Economy of Cities; Random House: New York, NY, USA, 1969.

79. Lychagin, S.; Pinkse, J.; Slade, M.E.; Van Reenen, J. Spillovers in Space: Does Geography Matter? J. Ind. Econ. 2016, 64, 295-335. [CrossRef]

80. Bloom, N.; Schankerman, M.; Van Reenen, J. Identifying technology spillovers and product market rivalry. Econometrica 2013, 81, 1347-1393.

81. Garcia, A.; Jaumandreu, J.; Rodriguez, C. Innovation and Jobs: Evidence from Manufacturing Firms; MPRA Working Paper No. 1204; MPRA: Munich, Germany, 2004.

82. Bretschger, L.; Lechthaler, F.; Rausch, S.; Zhang, L. Knowledge diffusion, endogenous growth, and the costs of global climate policy. Eur. Econ. Rev. 2017, 93, 47-72. [CrossRef]

(C) 2018 by the authors. Licensee MDPI, Basel, Switzerland. This article is an open access article distributed under the terms and conditions of the Creative Commons Attribution (CC BY) license (http:/ / creativecommons.org/licenses/by/4.0/). 